\title{
Dynamic Effects of FDI, Trade Openness, Capital Formation and Human Capital on the Economic Growth Rate in the Least Developed Economies: Evidence from Nepal
}

\author{
Bishnu Kumar Adhikary
}

\begin{abstract}
The study investigates the linkage between FDI, trade openness, capital formation, human capital, and economic growth rate in Nepal using the vector error correction (VEC) model. The study reveals that a long-run equilibrium relationship exists between variables. Besides, trade openness and FDI have a dynamic positive effect on the GDP per capita growth rate in Nepal. On the other hand, human capital does not appear to be a significant factor, whereas capital formation demonstrates a negative association with rates of economic growth. The VEC based Granger causality test indicates that a unidirectional short-term causal flow runs between FDI, trade openness, and GDP per capita growth rate. However, the impulse response analysis reveals that this relationship is not stable rather volatile over time. The study suggests that Nepal should adopt more liberalized trade policy to attract foreign capitals and to ensure stable economic growth rate. Simultaneously, it needs to invest more in its human capital to reap spillover effects of foreign technologies on other sectors.
\end{abstract}

Index Terms - Capital formation, economic growth, FDI, human capital, Nepal, openness, VEC.

\section{INTRODUCTION}

Since the beginning of 1980 s, most of the developing and least developed economies adopted the market-led economic growth model, which include, inter alia, greater trade openness, opening up markets for foreign direct investment (FDI) and development of human capital by sharing technologies and knowledge across economies, to enhance their economic growth rate. A large body of empirical literature also examined the efficacy of the market-led growth hypothesis taking into account various macroeconomic factors and the flows of FDI in the growth regression. However, little has been known till date on the dynamic effects of FDI, trade openness, capital formation, human capital, and the economic growth rate especially for the least developed economies. This paper fills this gap by examining Nepal as a least developed economy.

Nepal is taken as a case because (1) Nepal is regarded as one of the least performing economies in the South Asia in terms of the GDP growth rate and flows of foreign capitals, although it has significantly opened its economy since the mid-1980s to promote the economic growth rate, and (2) it

Manuscript received June 30, 2014; revised December 22, 2014

Bishnu Kumar Adhikary is with the Graduate School of Business Administration, Kobe University, Japan (e-mail: bishnu_adhikary@people.kobe-u.ac.jp, adhikarykobejp@gmail.com). encourages FDI by offering attractive fiscal and non-fiscal incentives to the foreign investors. Besides, any study is undertaken so far on the linkage between FDI, trade openness, capital formation, human capital, and economic growth rate in the context of Nepal.

The study of the linkage between FDI, trade openness, capital formation, human capital, and the economic performance of a least developed country deserves attention for several reasons. Firstly, FDI is likely to promote economic growth in a least developed country by increasing volume as well as marginal productivity of investment [1]-[4]. Furthermore, FDI can stimulate economic growth by increasing technological spillovers, widening the scope of international competition and strengthening the supply side capabilities of a host country.

Secondly, economies with a higher degree of trade openness tend to grow faster than the economies with a lower degree of trade openness because the former can absorb new technologies at a faster rate. Trade openness also reduces transaction cost (reduction of tariff and non-tariff barriers on investment and lubrication cost of doing business) of investment and promotes allocative efficiency of investment by reorienting factors of production in sectors that have a relative advantage in trade, thereby enhancing economic growth rate [5], [6].

Thirdly, the level of capital formation is assumed to influence the economic growth rate of a country as well. This is because economies with lower initial stock of capitals can generate higher marginal rate of returns (productivity) when additional capital is supplied into the productive sectors. Similarly, greater level of human capital (skilled and knowledgeable human force) tends to push the growth of aggregate output, prevent the falling of marginal product, increase cross sharing of knowledge and reverse engineering, thereby fostering economic growth [7].

In sum, FDI supplies much needed capital and technology, which, in effect, help build fixed capital of a country; trade openness facilitates FDI and redirects factor endowments to more productive sectors; higher degree of capital stocks ensures required finance for growth; progress in human capital enhances production efficiency; and they collectively tend to promote economic growth in the long-run. However, a question arises - does this relationship work empirically in the context of the least developed economies? This paper examines the above question taking Nepal as a case.

The remainder of the paper is organized as follows: Section II underpins theories and surveys related literature. Section III describes the data and statistical model. Section IV reports the empirical results. Section V concludes with a policy remark. 


\section{THEORETICAL UNDERPINNINGS AND SURVEY OF RELATED LITERATURE}

The neoclassical and the endogenous growth models can be considered as a theoretical foundation for the FDI-led economic growth hypothesis. The neoclassical growth model assumes that FDI can promote economic growth in a capital shortage economy by increasing the volume of physical investment and the marginal productivity of capital. In other words, the neoclassical growth model stresses that as capital input follows the law of diminishing rate of returns, economies with lower capital stocks can enhance economic growth rates at least in the short-run by ensuring availability of finance needed to the productive sectors. On the same note, Nath stated that FDI helps accumulate less volatile capital and increase in factor productivity of investment - a twin factor necessary for augmenting economic growth [8].

On the other hand, the endogenous growth theory, which is also referred to as the new growth theory, recognizes several modern inputs of economic growth such as organizational, managerial, technical and human skills, innovation and technological progress, and accumulation of knowledge besides the traditional labor and capital [3], [4], [9], [10]. In empirical works, Balasubramanyam et al. studied the FDI-led economic growth hypothesis on 46 developing economies and report that FDI exhibits significant and positive effect on the economic growth rate in economies that have higher educated workforce and trade polices conducive to exports [5]. Likewise, a study conducted by Zhang on eleven Latin American and Asian economies reveals that FDI generates more growth possibilities for the Asian economies than those of the Latin Americas [11]. He concludes that if a country adopts liberalized trade policy, takes initiative to improve education level and ensures macroeconomic stability, ceteris paribus, the economic growth rate of that country is more likely to increase due to higher flows of international capitals and technology spillovers.

By contrast, the dependency theorists argue that dependence on foreign investment may adversely affect the host country's economic growth and income distribution [note 1]. The dependency theorists argue that a country may grow in a disarticulated manner, instead of developing organically, when excessive reliance is placed on the FDI [12], [13]. This happens because the demand elasticity between two sectors is often to be less than unitary in a developing country [12]. Besides, foreign gigantic players may invariably exploit capitals, technologies, and marketing networks to shrink the growth and development of the domestic firms [14], [15]. In addition, the critics of modernization theories identify several macroeconomic factors such as employment, income distribution, balance-of-payments position and foreign exchange reserves, which may be negatively affected due to higher dependence on FDI.

With respect to the link between trade openness and economic growth, endogenous growth theory [3], [4], transaction cost theory [16], [17] and international product life cycle theory [18] can be put into place. Endogenous growth theorists argue that a more open trade regime allows a country to reorient factors of production into the sectors that have higher potential to grow. As factor endowments are better utilized due to increased trade openness, a country can obtain higher equilibrium growth rate in the long-run through increasing specializations and lowering cost of inputs [19]. Empirically, Solow reported that trade openness creates a room for technological progress and efficiency in allocating inputs as it eliminates protection given to the import substitution-industries [6]. Likewise, Grossman and Helpman, and Barro and Sala-I-Martin mentioned that economies with higher degree of economic openness have greater ability to absorb technological developments of the advanced economies. In effect, they can grow more rapidly than economies with lower degree of economic openness [2], [20].

However, Edwards argued that the poorer economies can grow faster than the advanced economies when the imitation cost of innovation in the poorer economies becomes lower than the cost of innovation in the technologically advanced economies [21]. This hypothesis supports the transaction cost theory in that markets for the intermediary products are usually imperfect and, firms, as economic agents, need to incur certain costs to complete a transaction. This transaction cost is significantly reduced when markets become integrated both at the national and the international level through greater economic openness or free trade, in particular. By the same token, Vernon discussed "product life cycle theory" and argued that innovative firms tend to relocate production processes and technologies into the low transaction cost economies in order to receive scale benefits and to export products into the richer economies at a lower cost [18]. This implies that the faster the technology moves from the advanced economies to the poorer economies via the trade openness (international trade), ceteris paribus, the faster the diffusion process is likely to be in the poorer economies [22]. World Bank also confirmed the importance of absorptive capacities in enhancing the economic growth rate of Malaysia and Taiwan [23].

Nonetheless, several studies document negative relationship between trade openness and economic growth. For instance, Rodrick claimed that higher economic openness invites macroeconomic instability by pushing inflation, depreciating currencies and creating balance of payment crisis [24]. Similarly, Levine and Renelt, and Andriamananjara and Nash reported that a more liberalized trade regime leads to a greater exchange rate depreciation by reducing aggregate supply of inputs, increasing prices of the imported inputs, and decreasing the volume of domestic outputs [25], [26]. Krugman further noted that the degree of trade openness, particularly the magnitude of tariff and non-tariff barriers, can, at best, influence a country's volume of trade, not its economic growth [27].

As regards to the connection between capital accumulation and economic growth, a more conclusive view is found both in theoretical and empirical literature. For instance, the neoclassical growth model argues that higher capital accumulation helps increase in economic growth rate by creating additional employment opportunities, expanding production bases, actuating savings, and increasing confidence in undertaking larger investment. Empirical works also support this inference. For instance, Kormendi and Meguire, Barro, and Levine and Renalt noted positive association between physical capital formation and economic growth rate of a country [26], [28], [29]. Blomstorm et al. 
reported a unidirectional causal relationship between fixed investment and economic growth [30]. Ghali and Ahmed applied time series analysis on G-7 economies and noted that the causality between fixed investment (capital formation) and economic growth is bi-directional and country specific [31]. Kendrick, however, argued that the amount of capital formation does not promote economic growth rather the efficiency in allocating capital into the productive sectors promotes growth [32].

As for the link between human capital and economic growth, empirical literature tends to be mystified. For instance, the World Bank reported that a $10 \%$ increase in human capital (proxied as secondary school enrollment ratio) can increase per capita GDP growth rate by a $0.30 \%$ point [33]. Likewise, Sianesi and Van Reenen unveiled that an overall $1 \%$ increase in the secondary school enrolment rates can increase in GDP per capita growth rate between $1 \%$ and $3 \%$ point [34]. They further report that an increase in additional one year secondary education (not the flow into education) can increase economic growth rate by more than $1 \%$ in each year. Similarly, Mankiw et al., and Barro and Sala-I-Martin documented positive association between the period of schooling and rates of economic growth [1], [9]. On the contrary, Pritchett did not find any relationship between human capital and rates of economic growth. He argues that a country's institutional/governance environment may be too perverse or the educational quality may be too poor to create any positive impact of the human capital on economic growth [35]. Similarly, Benhabib and Spiegel did not find any significant relationship between human capital and economic growth rate of a country [36].

In sum, empirical literature on the linkage between FDI, trade openness, capital formation, human capital, and economic growth is inconclusive. As Chakrabarti noted such sparse and skewed empirical results are primarily attributed to the authors' perspectives, sample selection, methodologies and analytical tools applied in the study [37]. Besides, the country specific characteristics such as economical, technological, infrastructural and institutional developments indeed matter a lot in obtaining confounding results. This study, thus, attempts to examine Nepal as a country specific case to add knowledge.

\section{DATA DESCRIPTIONS AND STATISTICAL MODEL}

To trace the dynamic relationship between FDI, trade openness, capital formation, human capital, and economic growth rate in Nepal, the study uses annual data over the period 1985-2012 which covers Nepal's long economic reform era till date. The per capita GDP growth rate is taken as an indicator of economic growth. FDI is normalized by real GDP. Trade openness is measured by export and import as a percentage of GDP following Gries et al., and Yanikkaya [38] [39]. Capital formation is expressed as a percentage of gross fixed capital formation over GDP. This measure is also adopted by Ghali and Ahmed, Levine and Renelt, and Barro [26], [28], [31]. Human capital is proxied by the secondary school enrollment ratio following Barro and Sala-I-Martin, and Sianesi and Van Reenen [1], [34]. Data used in the study is obtained from the World Development Indicators (the
World Bank) and the Ministry of Education, Nepal.

For empirical design, the study begins with a Cob-Douglas production function, as follows:

$$
Y_{t}=f\left(K^{\alpha} L^{1-\alpha}\right)
$$

where, $Y$ is the gross output produced in an economy in a given period $t$, and $K$ and $L$ are the capital and labor as factors of production during the same period, $t$. According to the growth accounting model, the growth can be affected by the degree of trade openness, human capital, capital formation, and so on. Therefore, the equation number (1) is augmented as follows:

$$
Y_{t}=A_{t} K_{d t}^{\alpha} K_{f t}^{\beta} O_{t}^{\varphi} H_{t}^{\varsigma}
$$

where, $Y$ is the gross output produced in an economy, and $K_{d}, K_{f}, O$ and $H$ represent stock of domestic capital, amount of FDI, degree of trade openness, and level of human capital, respectively. $A$ is the total factor productivity. The subscript $(t)$ denotes the year.

Now, taking logarithmic transformation and differentiating both sides of equation (2) with respect to time, the equation (2) is written as follows:

$$
Y_{t}=\alpha_{i}+\alpha K_{d t}+\beta K_{f t}+\varphi O_{t}+\zeta H_{t}
$$

In equation (3), the growth rate of output has been decomposed into the growth of total factor productivity and a weighted average of the growth rates of domestic capital, FDI, trade openness and human capital. $\alpha, \beta, \varphi$, and $\zeta$ represent the output elasticity of domestic capital, FDI, trade openness and human capital, respectively. The subscript $(t)$ denotes the year.

Taking equation number (3) into account, the final form of the equation is expressed as follows:

$$
\begin{gathered}
G P C G_{t}=\lambda+\beta F D I G D P_{t}+\psi O P E N_{t}+\varphi C F_{t}+ \\
\zeta H C_{t}+\varepsilon_{t}
\end{gathered}
$$

where, GPCG = GDP per capita growth, FDIGDP = FDI over GDP in percentage, OPEN = degree of trade openness, $\mathrm{CF}=$ capital formation, and $\mathrm{HC}=$ level of human capital. The expected signs of the parameters are: $\alpha>0, \beta>0, \Psi>0 \varphi>0$, and $\zeta>0$. The error-term $(\varepsilon)$ is assumed to be independently and identically distributed. The subscript $(t)$ indexes time.

For execution of the empirical design, the study proceeds as follows. First, the nature of the data distribution is examined by using the standard descriptive statistics (mean, median, standard deviation, skewness and kurtosis). Normality of data distribution is also checked by invoking the Jarque-Bera test. Second, the time series property of the group variable is checked using Levin Lin and Chu test.

Third, the cointegrating relationship among variables (tendency for variables to move together in the long-run) is studied by the Johansen-Juselius procedure to overcome the associated problem of spurious correlation and misleading inferences [40]-[42]. The cointegrating rank, $r$, can be formally tested with maximum eigenvalue test $\left(\lambda_{\max }\right)$ and the 
trace test $\left(\lambda_{\text {trace }}\right)$. These are computed as follows:

$$
\lambda_{\max }=-T \log \left(1-\lambda_{r+1}\right)
$$

where, the appropriate null is $\mathrm{r}=\mathrm{g}$ cointegrating vectors with ( $g=0,1,2,3,---)$ against the alternative that $r \leq g+1$.

$$
\lambda_{\text {trace }}=-T \sum_{i=r+1}^{k} \log \left(1-\lambda_{i}\right)
$$

where, the null is $r=g$ against the more general alternative $r \leq 1$.

Fourth, on the evidence of cointegrating relationship, a vector error-correction (VEC) model is estimated to study the long-run causality and the short-term dynamics. The purpose of the VEC model is to indicate the speed of adjustment from the short-run equilibrium to the long-run equilibrium state. Considering the base equation (4), The VEC model is specified as follows:

$$
\begin{gathered}
\Delta \text { GPCG }_{t}=\alpha+\lambda e_{t-1}+\sum_{i=1}^{n} b i \Delta G P C G_{t-i}+\sum_{i=1}^{m} c i \Delta F D I G D P_{t-i} \\
+\sum_{i=1}^{o} d i \Delta O P E N_{t-i}+\sum_{i=1}^{p} e i \Delta C F_{t-i}+\sum_{i=1}^{q} f i \Delta H C_{t-i}+\varepsilon_{t}
\end{gathered}
$$

In this specification, a long-run convergence process works between variables if the parameter $(\lambda)$ of the error correction term is found to be negative and statistically significant in terms of its associated-t value. In addition, changes in FDI, trade openness, capital formation and human capital Granger cause the changes in GDP per capita growth rates when $c_{i}$ 's, $d_{i}$ 's, $e_{i}$ 's and $f_{i}$ 's are to be significant in terms of the F-test [43].

It is to be noted that the Granger causality test can be performed on stationary data under a bivariate framework, which takes the following form:

$$
\begin{gathered}
Y_{t}=\alpha_{0}+\alpha_{1} Y_{t-1}+\alpha_{2} Y_{t-2}+---\alpha_{n} Y_{t-n}+ \\
\beta_{1} F D I_{t-1}+\beta_{2} F D I_{t-2}+---\beta_{n} F D I_{t-n}+\mu_{t} \\
F D I_{t}=\alpha_{0}+\alpha_{1} F D I_{t-1}+\alpha_{2} F D I_{t-2}+--\alpha_{n} F D I_{t-n}+ \\
\beta_{1} Y_{t-1}+\beta_{2} Y_{t-2}+---\beta_{n} Y_{t-n}+\varepsilon_{t}
\end{gathered}
$$

where, 1, 2-- $n$ is the lag length and, $\varepsilon_{t}$ and $\mu_{t}$ are error terms.

According to the above equations, the lagged values of both explanatory and dependent variables are used to test their effects on the dependent variable. The dependent variable, say $Y$, is said to be Granger-caused by the explanatory variable, say FDI, if FDI helps in improving the explanation of $Y$, or in other words, the coefficients of the lagged DI's are statistically significant. It is possible that a two way causality may run between the variables, i.e., FDI Granger causes $Y$, and $Y$ Granger causes FDI. The null hypothesis in this framework is:

$$
\beta_{1}=\beta_{2}=-----\beta_{1}=0
$$

However, it is argued that the simple bivariate causality measure does not yield better result, as it does not take into account the cointegration relationship among the variables or for that matter the error correction term. Thus, in this paper, the VAR based Granger causality test is used which produces efficient result.

Additionally, impulse response analysis is performed by giving a shock of one standard deviation ( \pm 2 S.E. innovations) to FDI, trade openness, capital formation and human capital to visualize the duration of their effects on the per capita GDP growth rate. In the end, a variance decomposition analysis is conducted to gain additional insights.

\section{EMPIRICAL RESULTS}

\section{A. Descriptive Statistics}

Table I provides the descriptive statistics of the variables in terms of their mean, median standard deviation, skewness, kurtosis, and Jarque-Bera t-statistics. The variables confirm normality. For instance, the mean-to-median ratio for each variable takes the value nearly one, except for FDIGDP. The standard deviation for each variable is also found low as

\begin{tabular}{|c|c|c|c|c|c|}
\hline \multicolumn{6}{|c|}{ TABLE I: DESCRIPTIVE STATISTICS } \\
\hline & GPCG & FDIGDP & $\mathrm{CF}$ & $\mathrm{HC}$ & OPEN \\
\hline Mean & 2.47 & 0.22 & 20.23 & 42.96 & 45.23 \\
\hline Median & 2.23 & 0.07 & 20.17 & 40.81 & 45.37 \\
\hline Maxima & 5.44 & 0.88 & 22.53 & 65.81 & 64.03 \\
\hline Minima & -1.73 & -0.09 & 16.12 & 27.46 & 31.52 \\
\hline Std. Dev. & 1.60 & 0.27 & 1.48 & 10.04 & 9.19 \\
\hline Skewness & -0.39 & 0.91 & -0.65 & 0.59 & 0.13 \\
\hline Kurtosis & 3.58 & 2.75 & 3.27 & 2.68 & 2.21 \\
\hline Jarque-B & 1.13 & 3.95 & 2.09 & 1.76 & 0.80 \\
\hline Prob. & 0.56 & 0.13 & 0.35 & 0.41 & 0.66 \\
\hline Sum & 69.20 & 6.26 & 566 & 1203 & 1266 \\
\hline Sum Sq. Dev. & 69.19 & 1.99 & 59.62 & 2724 & 2282 \\
\hline Observations & 28 & 28 & 28 & 28 & 28 \\
\hline
\end{tabular}
compared to its mean value. Similarly, the low numeric of skewness confirms normality. By contrast, the numeric of kurtosis for GPCG and CF indicates higher value than the standard one (three), however, they do not seriously violate the assumption of normality. On the other hand, the Jarque-Bera test statistics for the individual series indicates normality of the distribution. On the whole, the variables appear to be normally distributed.

\section{B. Stationarity Results}

TABLE II: LEVIN LIN CHU UNIT ROOT TEST FOR STATIONARITY

\begin{tabular}{|l|l|l|l|}
\hline Method & Statistic & Prob.*** & $\begin{array}{l}\text { Cross } \\
\text { Sections (obs) }\end{array}$ \\
\hline Levin, Lin \& Chu t* (level) & -0.679 & 0.248 & $5(133)$ \\
\hline Levin, Lin \& Chu t* (1 $^{\text {st }}$ Diff $)$ & -9.871 & 0.000 & $5(129)$ \\
\hline
\end{tabular}

Null: Unit root (assumes common unit root process)

Table II presents results of the unit root test under the Levin Lin Chu procedure. Levin Lin Chu procedure produces superior result over the augmented Dickey Fuller (ADF) procedure when the variables are treated as a group. The Levin Lin $\mathrm{Chu}$ test reveals that the variables are non-stationary at the level form but stationary at their first differences, meaning that they are integrated in the same order 
at the first difference. In consequence, the Johansen co-integration test is applied to detect the long-term cointegrating relationship among the variables.

\section{Co-integration Results under the Johansen Co-integration Test}

Table III presents results of the Johansen co-integration test Accordingly, both the trace and maximum eigenvalue statistics identify one cointegrating relationship at the 5\% level of significance $\{$ panel III(a) and III(b) . Clearly, these tests indicate the presence of a long-run equilibrium relationship among variables. As a result, the VEC model (7) is implemented.

TABLE III: JOHANSEN MULTIVARIATE CO-INTEGRATION TEST PANEL: III(A)

\begin{tabular}{|l|l|l|l|l|}
\hline $\begin{array}{l}\text { Hypothesized } \\
\text { No. of CE(s) }\end{array}$ & $\begin{array}{l}\text { Eigen } \\
\text { Value }\end{array}$ & $\begin{array}{l}\text { Trace } \\
\text { Statistic }\end{array}$ & $\begin{array}{l}5 \% \\
\text { CV }\end{array}$ & P-Value** \\
\hline None * & 0.744 & 77.32 & 69.81 & 0.0111 \\
\hline At most 1 & 0.631 & 41.88 & 47.85 & 0.1619 \\
\hline At most 2 & 0.338 & 15.92 & 29.79 & 0.7177 \\
\hline $\begin{array}{l}* \text { denotes rejection of the hypothesis at the 5\% level. ** MacKinnon } \\
\text {-Haug-Michelis (1999) p-values. }\end{array}$ \\
\hline
\end{tabular}

\begin{tabular}{|c|c|c|c|c|}
\hline \multicolumn{5}{|c|}{ PANEL: III(B) } \\
\hline $\begin{array}{l}\text { Hypothesized } \\
\text { No. of CE(s) }\end{array}$ & $\begin{array}{l}\text { Eigen } \\
\text { Value }\end{array}$ & $\begin{array}{l}\text { Max-Eigen } \\
\text { Statistic }\end{array}$ & $\begin{array}{l}5 \% \\
\mathrm{CV}\end{array}$ & P- Value $* *$ \\
\hline None* & 0.744 & 35.44 & 33.87 & 0.0323 \\
\hline At most 1 & 0.631 & 25.96 & 27.58 & 0.0794 \\
\hline At most 2 & 0.338 & 10.75 & 21.13 & 0.6715 \\
\hline \multicolumn{5}{|c|}{$\begin{array}{l}\text { *denotes rejection of the hypothesis at the } 5 \% \text { level** MacKinnon } \\
\text {-Haug-Michelis (1999) p-values. }\end{array}$} \\
\hline \multicolumn{5}{|c|}{ Max-eigenvalue test indicates one cointegrating equation at the 5\% level } \\
\hline
\end{tabular}

TABLE IV: ESTIMATES OF VEC MODEL

TABLE IV: ESTIMATES OF VEC MODEL
\begin{tabular}{|l|l|l|l|l|}
\hline Variable & Coefficient & $\begin{array}{l}\text { Std. } \\
\text { Error }\end{array}$ & t-statistic & Prob. \\
\hline$\lambda e^{\wedge}{ }_{t-1}$ & -2.113 & 0.683 & -3.093 & 0.0029 \\
\hline$\Delta$ GPCG(-1) & 0.507 & 0.507 & 1.000 & 0.3208 \\
\hline$\Delta$ GPCG(-2) & -0.133 & 0.271 & -0.490 & 0.6254 \\
\hline$\Delta$ FDIGDP(-1) & 1.284 & 1.557 & 0.824 & 0.4124 \\
\hline$\Delta$ FDIGDP(-2) & 2.061 & 1.200 & 1.717 & 0.0975 \\
\hline$\Delta$ OPEN(-1) & 0.283 & 0.123 & 2.303 & 0.0245 \\
\hline$\Delta$ OPEN(-2) & 0.037 & 0.123 & 0.306 & 0.7604 \\
\hline$\Delta$ CF(-1) & -1.080 & 0.517 & -2.086 & 0.0408 \\
\hline$\Delta$ CF(-2) & -0.536 & 0.378 & -1.416 & 0.1613 \\
\hline$\Delta$ HC(-1) & 0.203 & 0.141 & 1.438 & 0.1551 \\
\hline$\Delta$ HC(-2) & -0.047 & 0.131 & -0.360 & 0.7199 \\
\hline R-squared & 0.813 & Adjusted R-squared & 0.6565 \\
\hline F-statistic & 5.17 & Durbin-Watson statistic & 2.17 \\
\hline
\end{tabular}

\section{Regression Results under the VEC Model}

Table IV presents regression results under the VEC model with two lags as selected by the AIC criterion. The regression results confirm that a strong long-run equilibrium relationship exists among the variables. This is evidenced by the estimated coefficient $(\lambda)$ of the error correction term $\left(e^{\wedge}{ }_{t-1}\right)$ which is negative and statistically significant in terms of its associated t-value. This also implies that FDI, human capital, trade openness, and level of capital formation jointly promotes economic growth rate in a least developed country in the long-run. Concerning the short-term relationship, trade

openness (OPEN) has a positive relation to the economic growth rate (GPCG) of Nepal. On the other hand, FDI tends to have a positive effect only at the $10 \%$ level of significance. However, human capital (HC) does not appear to be a significant factor to influence Nepal's economic growth rate. By contrast, capital formation has a negative influence on the GDP growth rate which is unexpected. As regards to the casual effects, a unidirectional casual flow is evidenced between capital formation, trade openness, and per capita GDP growth rate. The numeric of adjusted $R^{2}(0.6565)$ confirms robustness of the model. Likewise, the F statistics indicates that a strong feedback effect runs within the system. The robustness of the VEC model is checked through the test of the AR characteristics polynomial (Fig. 1).

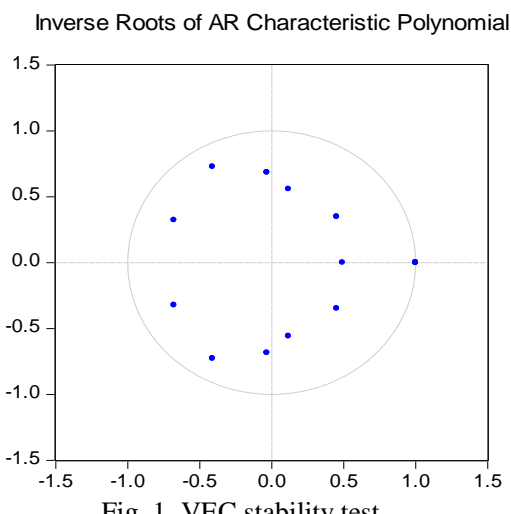

Fig. 1. VEC stability test.

Response to Cholesky One S.D. Innovations \pm 2 S.E.

Response of GPCG to GPCG

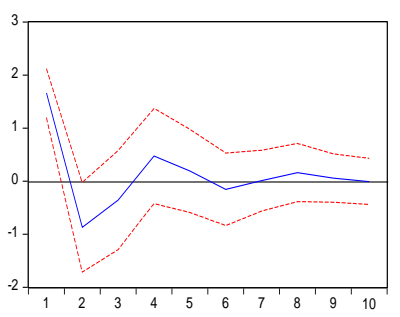

Response of GFCF to GPCG

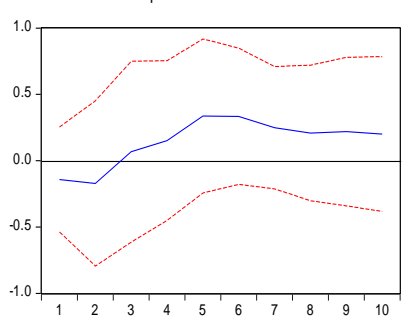

Response of OPEN to GPCG

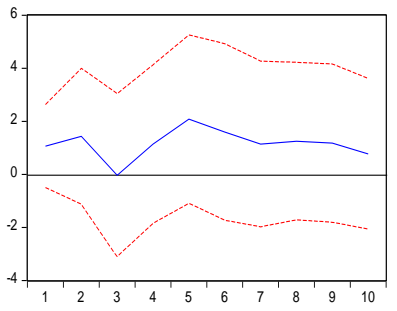

Fig. 2. Impulse response of FDIGDP, OPEN, CF, and HC on GPCG.

\section{E. Impulse Response and Variance Decomposition}

Fig. 2 reports the results of impulse response functions. Accordingly, the impulse response of OPEN and $\mathrm{HC}$ on the 
GDP per capita growth rates of Nepal are found to be always positive, although $\mathrm{HC}$ tends to be stable and flat after the fourth period. On the other hand, FDI shows a curvilinear trend till the seventh period. Afterwards, it becomes negative. A similar zigzag trend is also observed in the case of $\mathrm{CF}$. However, CF tends to influence GPCG positively from the third period onwards. As a whole, the impulse response function reveals that FDI, trade openness, and $\mathrm{HC}$ are positively associated with the economic growth rate of Nepal, whereas capital formation has a short-term negative effect but it becomes positive in the long-run.

The variance decomposition analysis reveals that the variability in GPCG is mainly bagged by its own variance (Table V). On the other hand, FDI and trade openness show an increasing power in explaining the variability of economic growth rates over time. By contrast, human capital and capital formation demonstrate week evidence in explaining the volatility of Nepal's economic growth rates - together they account for roughly $10 \%$.

TABLE V: VARIANCE DECOMPOSITION OF GPCG

\begin{tabular}{|l|l|l|l|l|l|}
\hline Period & GPCG & FDIGDP & OPEN & CF & HC \\
\hline 1 & 100.00 & 0.00 & 0.00 & 0.00 & 0.00 \\
\hline 2 & 87.18 & 5.11 & 0.00 & 0.056 & 7.64 \\
\hline 3 & 83.94 & 4.47 & 2.68 & 0.27 & 8.62 \\
\hline 4 & 72.00 & 7.56 & 12.65 & 0.25 & 7.50 \\
\hline 5 & 69.57 & 6.99 & 11.75 & 1.80 & 9.86 \\
\hline 6 & 64.83 & 9.32 & 13.46 & 2.69 & 9.67 \\
\hline 7 & 63.05 & 9.95 & 15.33 & 2.64 & 9.01 \\
\hline 8 & 62.85 & 9.93 & 15.24 & 2.70 & 9.254 \\
\hline 9 & 60.48 & 11.14 & 16.73 & 2.70 & 8.92 \\
\hline 10 & 59.45 & 11.57 & 17.75 & 2.63 & 8.58 \\
\hline
\end{tabular}

\section{SUMMARY AND POLICY IMPLICATIONS}

The study traced a long-term equilibrium relationship between FDI, trade openness, capital formation, human capital, and GDP per capita growth rate in Nepal. Furthermore, FDI and trade openness are found to have a dynamic positive effect on Nepal's economic growth rate. This implies that least developed economies such as Nepal should reduce tariff and non-tariff barriers to trade to attract more foreign direct investment and to promote economic growth as well. Interestingly, human capital (HC) did not appear to be a significant factor to cause Nepal's economic growth rate. This is possibly due to the poorer educational quality and lower educational enrollment rate in Nepal. On the other hand, capital formation demonstrated a negative relationship with the GDP growth rate in the short-run although it exhibited a positive impact in the long-run. One possible explanation may be that Nepal does not have a minimum threshold level of capital stock that can generate noticeable economic benefits in the short-run. Another reason could be embedded in other economic variables, such as persistent negative trade balance and weak financial stability of Nepal. Regarding the causal effects between variables, the VEC based Granger causality test indicated that a unidirectional short-term causal flow runs between FDI, trade openness, and GDP per capita growth rates in Nepal. However, the impulse response analysis revealed that such effects are not stable rather volatile over time. By contrast, human capital and capital stock demonstrated more stable influence on the GDP per capita growth rate. Finally, the variance decomposition analysis revealed that the variability in the Nepal's economic growth rate is mainly bagged by its previous economic growth rates although FDI and trade openness seem to accumulate higher explanatory power in the long-run.

Importantly, this study approves the earlier findings of Mortaza and Das, Sahoo, and Agrawal that identified a causal relationship between FDI and economic growth for all the South Asian economies [44]-[46]. Notably, those studies used panel analysis instead of country specific analysis. On the country specific front, this study disapproves the findings of Yan and Majagaiya, and Elliott and Kulkarni that identified no relationship between FDI and economic growth in Nepal [47], [48]. However, it approves the findings of Majagaiya and $\mathrm{Gu}$ that traced a long-term equilibrium relationship between FDI and economic growth rate [49]. Additionally, this study documented trade openness as a significant positive stimulus to the economic growth rate in Nepal.

The policy implications of this study are straight forward. The linkage between FDI, trade openness, capital formation, human capital, and economic growth rate is found to be integrated in the long-run, meaning that a long-run convergence process runs among them. This implies that Nepal should continue more liberalized trade policy to attract foreign capitals to ensure stable economic growth rate. In addition, Nepal should encourage both import-substitution and export-led investment to reduce its persistent negative trade balance. Simultaneously, it needs to invest more in its human capital to reap spillover effects of foreign technologies on other sectors.

\section{NOTE}

The dependency theory is introduced by Singer, and Prebisch to explain economic disparities between developed and developing economies [50], [51]. They argue that developing economies do not follow the same development paths which are followed by the developed economies, as each developing economy has a unique set of economic variables that guide their growth and development. They also claim that the terms of trade for the developing economies decreases when international transaction is done freely. Thus, they suggest that developing economies should seek growth based on their economic characteristics not by external pressure. This hypothesis is also known as the "Singer-Prebisch thesis" in international trade literature.

\section{REFERENCES}

[1] R. J. Barro and X. Sala-I-Martin, Economic Growth, McGraw Hill: New York, 1995.

[2] G. M. Grossman and H. Elhanan, Innovation and Growth in the Global Economy, Cambridge: MIT Press, 1991.

[3] R. E. Lucas, "On the mechanics of economic development," Journal of Monetary Economics, vol. 22, no. 1, pp. 3-42, 1988.

[4] P. M. Romer, "Increasing returns and long-run growth," Journal of Political Economy, vol. 94, no. 5, pp. 1002-1037, 1986.

[5] V. N. Balasubramanyam, M. Salisu, and D. Sapsford, "Foreign direct investment and growth in EP and is economies," The Economic Journal, vol. 106, no. 434, pp. 92-105, 1996.

[6] R. M. Solow, "A contribution to the theory of economic growth," The Quarterly Journal of Economics, vol. 70, pp. 65-94, 1956. 
[7] A. Habiyaremye and T. Ziesemer, Absorptive Capacity and Export Diversification in Sub-Saharan African Economies, Maastrich: United Nations University, 2006.

[8] H. K. Nath, "Trade, foreign direct investment and growth: Evidence from transition economies," Comparative Economic Studies, vol. 51, pp. 20-50, 2009.

[9] N. G. Mankiw, D. Romer, and D. N. Weil, "A contribution to the empirics of economic growth," The Quarterly Journal of Economics, vol. 107, no. 2, pp. 407-437, 1992.

[10] T. A. Pugel, International Economics, McGraw-Hill Irwin: New York, USA, 2007.

[11] K. H. Zhang, "Does foreign direct investment promote economic growth? Evidence from East Asia and Latin America," Contemporary Economic Policy, vol. 19, pp. 175-185, 2001.

[12] S. Adams, "Foreign direct investment, domestic investment and economic growth in Sub-Saharan Africa," Journal of Policy Modeling, vol. 31, pp. 939-949, 2009.

[13] S. Amin, Accumulation on a World Scale: A Critique of the Theory of Underdevelopment, New York: Monthly Review Press, 1974.

[14] R. M. Agosín and R. Mayer, "Foreign investment in developing economies: Does it crowd in domestic investment?" UNCTAD Discussion Paper, Geneva, Switzerland, no. 146, 2000.

[15] N. Kumar and J. P. Pradhan, "Foreign direct investment, externalities and economic growth in developing economies: some empirical explorations and implications for wto negotiations on investment," RIS Discussion Papers, no. 27/2002, New Delhi, 2002.

[16] R. H. Coase, "The nature of the firm," Economica, vol. 4, pp. 386-405, 1937.

[17] O. E. Williamson, "The economics of organization: The transaction cost approach," The American Journal of Sociology, vol. 87, no. 3, pp. 548-577, 1981

[18] R. Vernon, "International investment and international trade in the product cycle," Quarterly Journal of Economics, vol. 80, no. 2, pp. 190-207, 1966

[19] The origin of endogenous growth, Journal of Economic Perspectives, vol. 8, no. 1, pp. 3-22, 1994.

[20] R. J. Barro, N. G. Mankiw, and X. Sala-I-Martin, "Capital mobility in neoclassical models of growth," American Economic Review, vol. 85 , no. 1 , pp. 103-115, 1995

[21] S. Edwards, "Openness, productivity and growth: What do we really know?" Economic Journal, vol. 108, no. 447, pp. 383-398, 1998.

[22] W. J. Baumol, R. R. Nelson, and E. N. Wolff, Convergence of Productivity: Cross National Studies and Historical Evidence, New York: Oxford University Press, 1994.

[23] World Bank, Global Development Finance 2001: Building Coalitions for Effective Development Finance, 2001

[24] D. Rodrik, "The limits of trade policy reforms in developing economies," Journal of Economic Perspectives, vol. 6, no. 1, pp. 87-105, 1992.

[25] S. Andriamananjara and J. Nash, "Have trade policy reforms led to greater openness in developing economies?" World Bank Working Paper Series, no. 1730, 1997.

[26] R. Levine and D. Renelt, "A sensitivity analysis of cross-country regressions," The American Economic Review, vol. 82, no. 4, pp. 942-963, 1992.

[27] P. R. Krugman, "The myth of Asia's miracle," Foreign Affairs, vol. 73 , no. 6, pp. 62-78, 1994.

[28] R. J. Barro, "Economic growth in cross section of economies," Quarterly Journal of Economics, vol. 106, pp. 407-444, 1991

[29] R. C. Kormendi and P. G. Meguire, "Macroeconomic determinants of growth: cross-country evidence," Journal of Monetary Economics, vol. 16, no. 2, pp. 141-163, 1985.

[30] M. Blomstrom, R. E. Lipsey, and M. Zezan, "What explains the growth of developing economies?" in Convergence of Productivity, W. J. Baumol, R. R. Nelson, and E. N. Wolf, Eds. New York: Oxford University Press, 1994, pp. 243-256.

[31] K. Ghali and A.-M. Ahmed, "The intertemporal causal dynamics between fixed capital formation and economic growth in the group of seven economies," International Economic Journal, vol. 13, no. 2, pp. 31-37, 1999.

[32] J. W. Kendrick, "How much does capital explain?" in Explaining Economic Growth: Essays in Honour of Angus Maddison, A. Szirmai, B. V. Ark, and D. Pilat, Eds. Amsterdam: North Holland, 1993, pp. 129-146.

[33] World Bank, The East Asian Miracle: Economic Growth and Public Policy, USA: Oxford University Press, 1993.
[34] B. Sianesi and J. V. Reenen, "the returns to education: a review of the macro-economic literature," Discussion paper, Centre for the Economics of Education, no. 6, 2000.

[35] L. Pritchett, "Where has all the education gone?" World Bank Economic Review, vol. 15, pp. 367-391, 2001.

[36] J. Benhabib and M. M. Spiegel, "The role of human capital in economic development: Evidence from aggregate cross-country data," Journal of Monetary Economics, vol. 34, pp. 143-173, 1994.

[37] A. Chakrabarti, "The determinants of foreign direct investment: Sensitivity analyses of cross-country regressions," Kyklos., vol. 54, no. 1, pp. 89-113, 2001.

[38] T. Gries, T. M. Kraft, and D. Meierrieks, "Linkages between financial deepening, trade openness and economic development: Causality evidence from Sub-Saharan Africa," World Development, vol. 37, no. 12, pp.1849-1860, 2009.

[39] H. Yanikkaya, "Trade openness and economic growth: A Cross-country empirical investigation," Journal of Development Economies, vol. 72, pp. 57-89, 2003.

[40] S. Johansen, "Statistical analysis of cointegration vectors," Journal of Economic Dynamics and Control, vol. 12, no. 2-3, pp. 231-254, 1988.

[41] S. Johansen and K. Juselius, "Maximum likelihood estimation and inference on cointegration with applications to the demand for money," Oxford Bulletin of Statistics, vol. 52, no. 2, pp. 169-210, 1990.

[42] Testing structural hypothesis in multivariate cointegration analysis of the PPP and VIP for U.K., Journal of Econometrics, vol. 53, no. 1-3, pp. 211-244, 1992.

[43] M. Bahmani-Oskooee and S. Payesteh, "Budget deficits and the value of the dollar: An Application of cointegration and error-correction modeling," Journal of Macroeconomics, vol. 15, no. 4, pp. 661-677, 1993.

[44] P. Agrawal, "Economic impact of foreign direct investment in south asia," Indira Gandhi Institute of Development Research, Mumbai, India, 2000.

[45] M. G. Mortaza and N. C. Das, "Foreign direct investment, trade liberalization and economic growth: empirical evidence from south asia and implications for Bangladesh," Working Paper Series, Policy Analysis Unit, Bangladesh Bank, no. 0712, 2007.

[46] P. Sahoo, "Foreign direct investment in South Asia: Policy, trends, impact and determinants," ADB Institute Discussion Paper, no. 56, 2006.

[47] A. Elliot and K. G. Kulkarni, "Role of FDI in the economic development of Nepal," The IUP Journal of Applied Economics, vol. 5, no. 3, pp. 3-47, 2006.

[48] X. Yan and K. P. Majagaiyaa, "Relationship between foreign direct investment and economic growth: A case study of Nepal," International Journal of Business and Management, vol. 6, no. 6, pp. 42-246, 2011

[49] K. P. Majagaya and Q. Gu, "A time series analysis on foreign direct investment and economic growth: A case study of Nepal," International Journal of Business and Management, vol. 5, no. 2, pp. 144-148.

[50] R. Prebisch, The Economic Development of Latin America and Its Principle Problems, New York; United Nations, 1950.

[51] H. W. Singer, "The distribution of gains between investing and borrowing economies," American Economic Review, vol. XL, pp. 473-485, 1950.

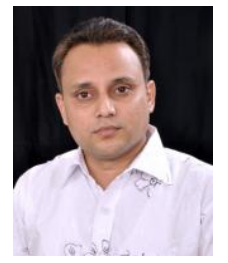

Bishnu Kumar Adhikary is an associate professor at the Graduate School of Business Administration at Kobe University, Japan. He holds a PhD degree in Asia Pacific Studies (FDI) from the Ritsumeikan Asia Pacific University, Beppu, Japan. He also holds MBA degree in finance from the Rtsumeikan Asia Pacific University, Beppu, Japan; MBA degree in marketing from the Calcutta University, Kolkata, India; an M.CoM degree in accounting from the Dhaka University, Dhaka, Bangladesh.

$\mathrm{He}$ has extensive experience in teaching accounting, finance, SME financing, financial analysis, corporate finance, and international finance. $\mathrm{He}$ is mainly interested in venture capital, SME financing, and international trade.

Dr. Adhikary has published articles in different reputed journals, including Journal of Asia Pacific Business Review, Journal of Contemporary South Asia, Journal of Comparative Asian Development, Journal of World Trade and Investment, and Asia Pacific World. 